\title{
Transformation of Group F Streptococci by Plasmid DNA
}

\author{
By DONALD J. LEBLANC, LINDA COHEN \\ AND LAUREN JENSEN \\ Laboratory of Microbiology and Immunology, National Institute of \\ Dental Research, National Institutes of Health, Bethesda, \\ Maryland 20014, U.S.A.
}

(Received 10 August 1977; revised 6 December 1977)

\begin{abstract}
When the Challis strain of Streptococcus sanguis was transformed by the 17 megadalton $\beta$ plasmid from Streptococcus faecalis strain DS5, the plasmid underwent a 1.5 megadalton deletion (LeBlanc \& Hassell, 1976). Furthermore, the covalently closed circular (CCC) plasmid DNA isolated from Challis transformants was rapidly converted to a linear form which did not possess any detectable transforming activity. To obtain stable CCC plasmid DNA a competent culture of a Lancefield group F streptococcus, strain DL8 (ATCC 12393), was used as a recipient of $\beta$ plasmid DNA. The plasmid DNA isolated from group F transformants exhibited the same configuration and size characteristics as the Ds5 $\beta$ plasmid, and the CCC configuration was stable upon storage. CCC plasmid DNA from a group F transformant was biologically active and, when added to competent cultures of strain DL8, transformed them at frequencies about 100-fold greater than did $\beta$ plasmid DNA from DS5. This suggests the existence of a restriction-modification system in strain DL8.
\end{abstract}

\section{INTRODUCTION}

Chromosomal DNA from group D streptococci has been used to transform competent group H strains and one strain of group F (Lancefield strain c628) (Perry \& Slade, 1962, 1964). We previously demonstrated the transformation of the Challis strain of Streptococcus sanguis (group H) by plasmid DNA isolated from S. faecalis (group D) (LeBlanc \& Hassell, 1976). Physical characterization of the plasmid molecule from Challis transformants showed that this DNA differed from the transforming plasmid in at least two ways: (i) the Challis plasmid was smaller than the plasmid from $S$. faecalis and (ii) the covalently closed circular (CCC) form of the plasmid from the transformant was rapidly converted to a linear doublestranded molecule. The latter property precluded the use of this system to assay for the presence of a restriction-modification system in S. sanguis, since it was not possible to effect transformation with non-circular plasmid DNA (LeBlanc, unpublished observations).

In this communication we describe the transformation of a Lancefield group F streptococcus by the $\beta$ plasmid from $S$. faecalis strain Ds5. Plasmid DNA isolated from these group $\mathrm{F}$ transformants was physically identical to the donor plasmid molecules, and the CCC configuration remained stable for several months at $4{ }^{\circ} \mathrm{C}$. By using this DNA as a donor in transformation reactions with competent group $\mathrm{F}$ cultures, evidence was obtained which suggests the presence of a restriction-modification system in this strain. 


\section{METHODS}

Bacterial strains and growth conditions. The transformable Challis strain of S. sanguis, DL1, and the DS5 strain of $S$. faecalis have been described previously (Clewell et al., 1974; LeBlanc \& Hassell, 1976). A transformable Lancefield group F strain (c628) (Perry \& Slade, 1962, 1964) was obtained from the American Type Culture Collection (ATCC 12393) and is here designated strain DL8.

Except for the transformation experiments, all cultures were grown in Todd-Hewitt broth (Difco) supplemented with $1 \%(\mathrm{w} / \mathrm{v})$ D-glucose (THB plus glucose). Solid media contained $1.5 \%(\mathrm{w} / \mathrm{v})$ agar (Difco). Blood broth, for growth of organisms prior to transformation, consisted of THB plus glucose containing $4 \%$ (w/v) sheep blood. Transformation medium (TM) was described previously (LeBlanc \& Hassell, 1976). All organisms were grown at $37{ }^{\circ} \mathrm{C}$ and plates were incubated in an atmosphere of $5 \% \mathrm{CO}_{2} / 95 \%$ air.

Labelling and extraction of DNA. Cultures were first grown in $5 \mathrm{ml}$ THB plus glucose; for strains resistant to erythromycin (Em), the medium also contained $25 \mu \mathrm{g} \mathrm{Em} \mathrm{ml}{ }^{-1}$. Exponentially growing cultures were added to $100 \mathrm{ml}$ THB plus glucose containing $20 \mathrm{mM}$-DL-threonine and either [ $\left.{ }^{3} \mathrm{H}\right]$ thymidine $\left(10 \mu \mathrm{Ci} \mathrm{ml}{ }^{-1}\right.$, 55 to $60 \mathrm{Ci} \mathrm{mmol}^{-1}$; Schwarz/Mann, Orangeburg, New Jersey, U.S.A.) or $\left[{ }^{14} \mathrm{C}\right]$ thymidine $\left(0 \cdot 4 \mu \mathrm{Ci} \mathrm{ml}{ }^{-1}\right.$, 45 to $60 \mathrm{mCi} \mathrm{mmol}^{-1}$; Schwarz/Mann) and incubated for 16 to $20 \mathrm{~h}$ (Em was not added to the labelling medium). For the preparation of labelled transforming plasmid DNA, organisms were grown in 800 to $1600 \mathrm{ml}$ of $\left[{ }^{14} \mathrm{C}\right]$ thymidine-containing medium. Cell lysates were prepared and DNA was extracted as described previously (LeBlanc \& Hassell, 1976).

Sedimentation techniques. Dye buoyant density gradient centrifugation and neutral sucrose gradient analysis were done as described by LeBlanc \& Hassell (1976). Alkaline sucrose gradient analysis was performed by layering a $0.2 \mathrm{ml}$ sample on to a $4.8 \mathrm{ml} 5$ to $20 \%(\mathrm{w} / \mathrm{v})$ linear sucrose gradient in buffer, pH 12.5 (containing $0.7 \mathrm{M}-\mathrm{NaCl}, 0.3 \mathrm{M}-\mathrm{NaOH}, 0.0025 \mathrm{M}$-EDTA and $0.015 \%(\mathrm{w} / \mathrm{v}$ ) sodium lauroyl sarcosinate) and centrifuging at $48000 \mathrm{rev} . \mathrm{min}^{-1}$ for $50 \mathrm{~min}$ at $10^{\circ} \mathrm{C}$ in the $\mathrm{SW} 50.1$ rotor. Samples were fractionated and counted as described for analytical neutral sucrose gradients (LeBlanc \& Hassell, 1976).

Transformation reactions. Strains were first grown in THB plus glucose. During exponential growth, $0.1 \mathrm{ml}$ was transferred to $5 \mathrm{ml}$ of warmed blood broth and incubated for $15 \mathrm{~h}$. This stationary phase culture was diluted 10 -fold in TM, generally to $1.5 \times 10^{7}$ to $2.5 \times 10^{7}$ colony-forming units (c.f.u.) $\mathrm{ml}^{-1}$, and incubated at $37^{\circ} \mathrm{C}$. At $1 \mathrm{~h}$ intervals, $0.9 \mathrm{ml}$ of TM culture was transferred to a tube containing $0.1 \mathrm{ml}$ of a solution of CCC $\beta$ plasmid DNA $\left(10 \mu \mathrm{g} \mathrm{ml}^{-1}\right)$ in $0.025 \mathrm{M}$-sodium phosphate buffer, $\mathrm{pH} 7 \cdot 5$. Controls were carried out by transferring culture samples to tubes containing $0.1 \mathrm{ml}$ of $0.025 \mathrm{M}$-sodium phosphate buffer without DNA. After $15 \mathrm{~min}, 0.1 \mathrm{ml}$ of a sterile solution of deoxyribonuclease $\left(2 \mathrm{mg} \mathrm{ml}^{-1}\right.$; bovine pancreas DNase I; Calbiochem) in $0.02 \mathrm{M}-\mathrm{MgSO}_{4}$ was added. Incubation was continued for an additional 105 min before plating. Transformants were isolated by spreading dilutions on THB plus glucose plus $1.5 \%(w / v)$ agar plates containing $25 \mu \mathrm{g} \mathrm{Em} \mathrm{m}{ }^{-1}$. Transformation frequencies were determined from the ratio of c.f.u. on plates containing Em to c.f.u. on plates without Em. All plates were incubated for 48 to $72 \mathrm{~h}$ before counting.

\section{RESULTS}

\section{Transformation of a group $F$ streptococcus by $\beta$ plasmid DNA}

Strain DL8 was transformed to Em resistance by CCC $\beta$ plasmid DNA. The cells were optimally competent $\left(1.7 \times 10^{-4}\right.$ transformants c.f.u. $\left.{ }^{-1}\right) 1 \mathrm{~h}$ after dilution of blood broth cultures, in agreement with previous results using chromosomal DNA (Perry \& Slade, 1964). No Em-resistant colonies were observed in any of the control cultures.

The $\beta$ plasmid also codes for resistance to the antibiotic lincomycin $(\mathrm{Lm})$, and the minimal inhibitory concentrations for $\mathrm{Em}$ and $\mathrm{Lm}$ in strain DS5 are both greater than $1 \mathrm{mg}$ $\mathrm{ml}^{-1}$ (Clewell et al., 1974). The DL8 strain, prior to transformation by the $\beta$ plasmid, is completely inhibited by $5 \mu \mathrm{g} \mathrm{Em} \mathrm{ml}^{-1}$ and $1 \mu \mathrm{g} \mathrm{Lm} \mathrm{ml}^{-1}$. In $\beta$ plasmid transformants of strain DL8, the minimal inhibitory concentration for Em was always greater than $1 \mathrm{mg} \mathrm{ml}^{-1}$ but $\mathrm{Lm}$ at less than $1 \mathrm{mg} \mathrm{ml}^{-1}$ (500 to $900 \mu \mathrm{g} \mathrm{m}^{-1}$ ) completely inhibited growth. Transformants of $S$. sanguis were also less resistant to $\mathrm{Lm}\left(250 \mu \mathrm{g} \mathrm{ml}^{-1}\right)$ than was DS5 (LeBlanc \& Hassell, 1976). However, all transformants resistant to Em were also resistant to $\mathrm{Lm}$.

\section{Characterization of plasmid DNA from group $F$ transformants}

DNA from $\left[{ }^{3} \mathrm{H}\right]$ thymidine-labelled cultures of strain DL8 and DL8 transformants was extracted and banded in ethidium bromide-caesium chloride equilibrium gradients. Strain 


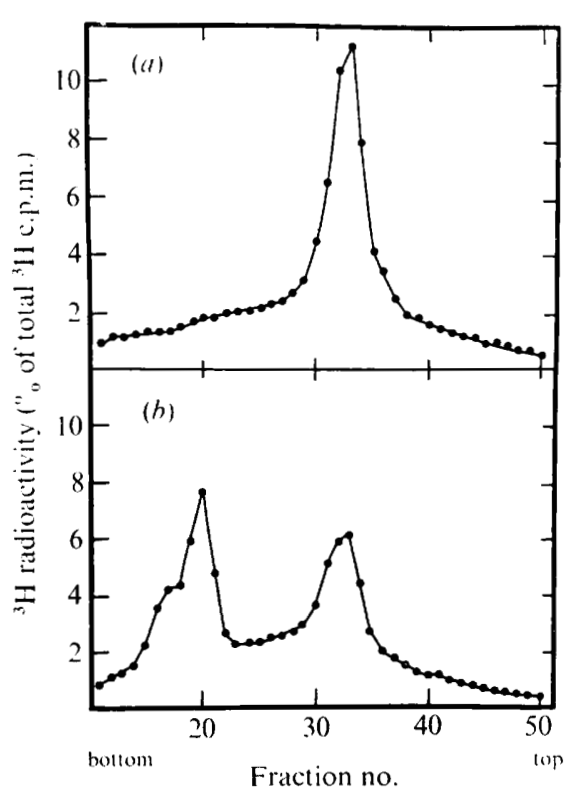

Fig. 1

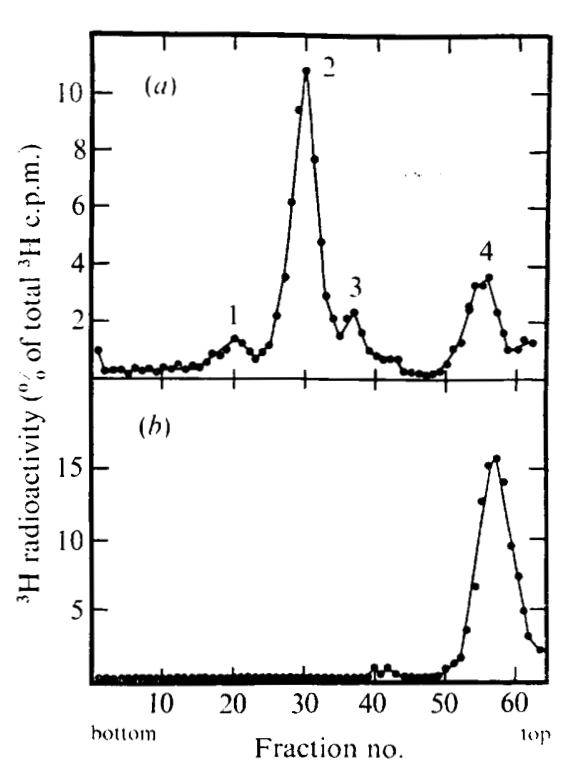

Fig. 2

Fig. 1. Ethidium bromide-caesium chloride buoyant density gradient centrifugation of DNA from strain DL8 and strain DL8-12, a $\beta$ plasmid transformant of DL8. (a) DL8 DNA; total ${ }^{3} \mathrm{H}$ in gradient, 47700 c.p.m. (b) DL8-12 DNA; total ${ }^{3} \mathrm{H}$ in gradient, 172000 c.p.m.

Fig. 2. Preparative neutral sucrose gradient analysis of DL8 and DL8-12 DNA in pooled fractions from dye buoyant density gradients. (a) DL8-12 plasmid DNA (fractions 16 to 24 , Fig. $1 b$ ); total ${ }^{3} \mathrm{H}$ in gradient, 29200 c.p.m. (b) DL8 DNA (fractions 16 to 24 , Fig. $1 a$ ); total ${ }^{3} \mathrm{H}$ in gradient, 3700 c.p.m.

DL8 produced only a single peak in these gradients, corresponding to chromosomal DNA (Fig. 1a). A second peak, banding in the region of CCC plasmid DNA, was seen in all gradients derived from Em-resistant transformants of DL8 (Fig. 1b).

Fractions corresponding to the plasmid peak in Fig. 1(b) were pooled for further characterization of the DNA. After extraction of ethidium bromide and dialysis to remove caesium chloride, the DNA was sedimented through a preparative $(36 \mathrm{ml})$ neutral sucrose gradient. Acid-precipitable radioactivity was found in four peaks in the gradient (Fig. $2 a$ ). Peak number 4 did not appear to be $\beta$ plasmid DNA, since it corresponded to a peak seen in a similar gradient (Fig. $2 b$ ) loaded with radioactive material obtained from fractions 16 to 24 of the dye buoyant density gradient in Fig. 1(a) (DL8, untransformed). The $\beta$ plasmid from $S$. faecalis strain DS 5 has a molecular weight of $17 \times 10^{6}$. In neutral sucrose gradients the CCC form of $\beta$ sediments at $43 \mathrm{~S}$ and the relaxed circular (OC) form sediments at $31 \mathrm{~S}$ (Clewell et al., 1974). Peaks 2 and 3 in Fig. 2(a), as shown below, corresponded to 43S (CCC) and $31 \mathrm{~S}$ (OC) $\beta$ plasmid DNA, respectively. Peak 1 sedimented at the rate (56S) expected for a CCC dimer of a 17 megadalton molecule. Preliminary evidence suggests that the 56S species is, in fact, a dimeric form of the $\beta$ plasmid (LeBlanc, unpublished observations).

In previous studies on the behaviour of $\beta$ plasmid DNA isolated from transformed $S$. sanguis clones, the CCC form was shown to sediment at $41 \mathrm{~S}$ in neutral sucrose gradients, suggesting a deletion of 1.5 megadaltons from the transforming $\beta$ plasmid (LeBlanc $\&$ Hassell, 1976). In addition, this $41 \mathrm{~S}$ plasmid was rapidly converted to a $24 \mathrm{~S}$ linear doublestranded molecule. Since peaks 2 and 3 from the gradient in Fig. 2(a) appeared to represent 43S (CCC) and $31 \mathrm{~S} \mathrm{(OC)} \mathrm{forms} \mathrm{of} \mathrm{the} \beta$ plasmid, the fractions in these regions were pooled separately, dialysed and further examined in analytical neutral and alkaline sucrose gradients. 


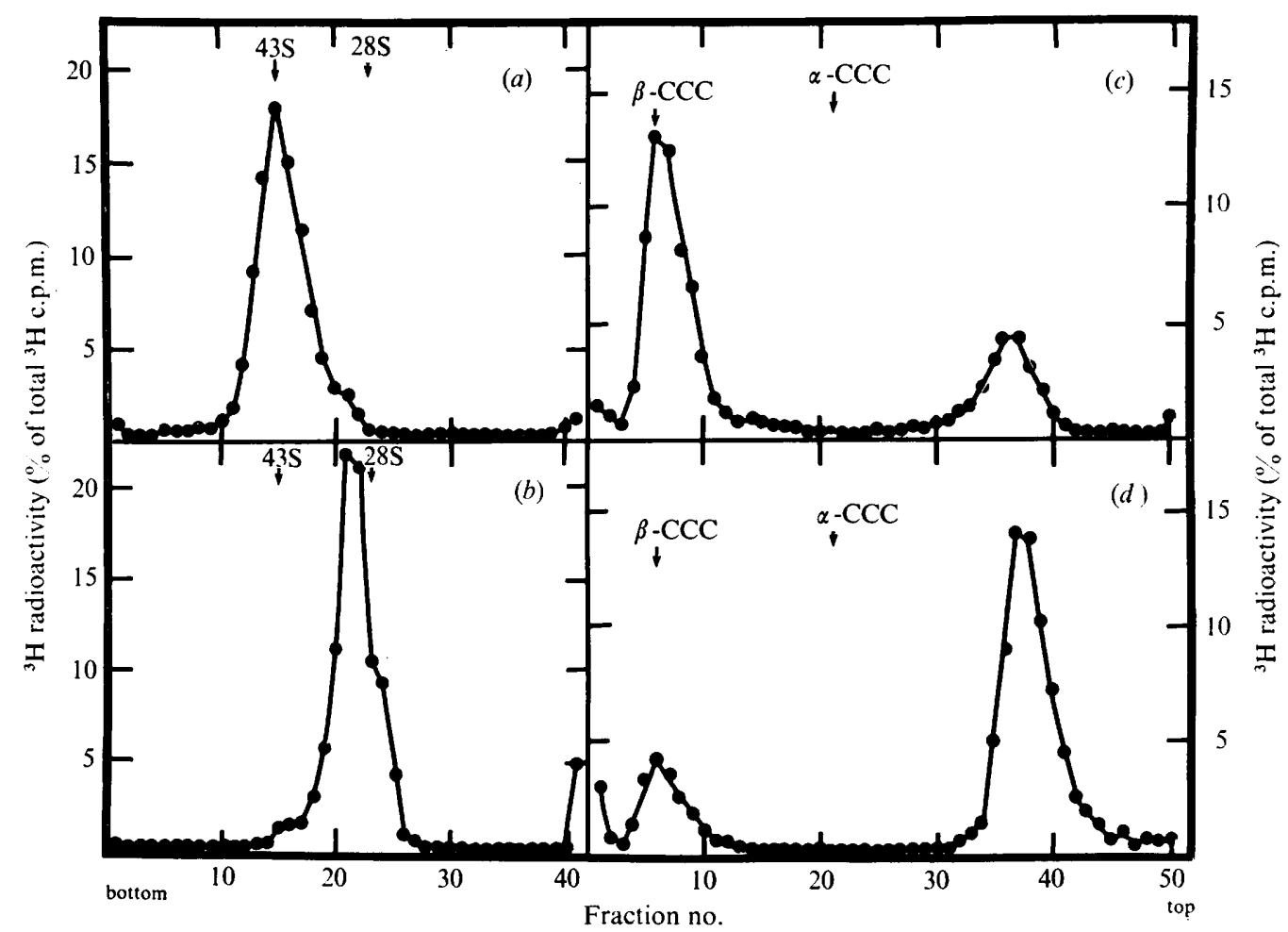

Fig. 3. Neutral and alkaline sucrose gradient analyses of major plasmid species from strain DL8-12. Fractions corresponding to peaks 2 and 3 in Fig. 2(a) were pooled, dialysed and sedimented through analytical neutral and alkaline sucrose gradients as described in Methods. ${ }^{14} \mathrm{C}$-labelled CCC $\beta$ plasmid and $\alpha$ plasmid DNA, isolated from strain DS5, were included as internal markers in all gradients. (a) Peak 2, neutral sucrose; total ${ }^{3} \mathrm{H}$ in gradient, 5400 c.p.m. (b) Peak 3, neutral sucrose; total ${ }^{3} \mathrm{H}$ in gradient, 2000 c.p.m. (c) Peak 2, alkaline sucrose; total ${ }^{3} \mathrm{H}$ in gradient, 5800 c.p.m. $(d)$ Peak 3, alkaline sucrose; total ${ }^{3} \mathrm{H}$ in gradient, 2200 c.p.m. The positions of the ${ }^{14} \mathrm{C}$-labelled internal markers are indicated by the arrows.

When the ${ }^{3} \mathrm{H}$-labelled material from peak 2 was mixed with ${ }^{14} \mathrm{C}$-labelled $43 \mathrm{~S} \beta$ plasmid DNA from strain DS5 and sedimented in a 5 to $20 \%(\mathrm{w} / \mathrm{v})$ linear neutral sucrose gradient, both of the labels sedimented at 43S (Fig. 3a). Confirmation of the CCC configuration of the peak 2 material was obtained on a 5 to $20 \%$ (w/v) alkaline sucrose gradient, in which both ${ }^{3} \mathrm{H}$-labelled peak 2 DNA and ${ }^{14} \mathrm{C}$-labelled CCC $\beta$ plasmid DNA again sedimented together (Fig. $3 c$ ). Peak 3 DNA, when mixed with ${ }^{14} \mathrm{C}$-labelled $43 \mathrm{~S} \beta$ plasmid DNA and ${ }^{14}$ C-labelled 28S CCC $\alpha$ plasmid DNA (Clewell et al., 1974), sedimented in neutral sucrose between these two internal markers (Fig. $3 b$ ). The calculated sedimentation rate of the peak 3 species was $31 \mathrm{~S}$, the rate expected for an open circle of a 17 megadalton molecule. Alkaline sucrose gradient analysis of the peak 3 species showed that this DNA sedimented at a rate which was considerably slower than either the $\beta$ or $\alpha \mathrm{CCC}$ forms (Fig. 3d). In this gradient it was not possible to distinguish between the alkaline denatured products of an open circular or linear duplex. However, based on the sedimentation rate of peak 3 DNA in the neutral sucrose gradient (Fig. $3 b$ ), it would appear that peak 3 was the OC form of the 43S CCC species.

CCC $\beta$ plasmid DNA isolated from strain Ds5 remains in this state for months when stored at $4{ }^{\circ} \mathrm{C}$, with only a small percentage of the molecules being converted to the $\mathrm{OC}$ configuration. The $41 \mathrm{~S} \mathrm{CCC} \mathrm{form} \mathrm{of} \mathrm{the} \beta$ plasmid isolated from transformed $S$. sanguis is very unstable, being rapidly converted to the linear duplex (LeBlanc \& Hassell, 1976). 
Table 1. Transformation of group F streptococci by CCC $\beta$ plasmid DNA isolated from strains DS5 or DL8-12

\begin{tabular}{|c|c|c|c|}
\hline \multirow[b]{2}{*}{$\begin{array}{l}\text { Time of incubation* } \\
\text { (h) }\end{array}$} & \multicolumn{3}{|c|}{ Transformation frequency $\dagger$} \\
\hline & $\beta$ (from Ds5) & $\beta$ (from DL8-12) & $\frac{\beta \text { (DL8-12) }}{\beta \text { (DS5) }}$ \\
\hline $\begin{array}{l}1 \\
2 \\
3 \\
4 \\
5\end{array}$ & $\begin{array}{l}1 \cdot 7 \times 10^{-4} \\
4.4 \times 10^{-6} \\
1 \cdot 3 \times 10^{-6} \\
8 \cdot 0 \times 10^{-7} \\
8 \cdot 8 \times 10^{-7}\end{array}$ & $\begin{array}{l}1.1 \times 10^{-2} \\
1.2 \times 10^{-4} \\
5.4 \times 10^{-5} \\
5.4 \times 10^{-5} \\
2.5 \times 10^{-5}\end{array}$ & $\begin{array}{l}65 \\
27 \\
45 \\
67 \\
28\end{array}$ \\
\hline
\end{tabular}

In this regard, the $\beta$ plasmid from transformed DL 8 clones behaved more like the DNA from the original host (DS5).

\section{Spontaneous curing of erythromycin resistance in group $F$ transformants}

In several early experiments with DL8 transformants it was observed that very little plasmid DNA could be recovered from cultures unless the organisms had been grown in the presence of Em prior to transfer to the labelling medium. To examine this further, transformed clones which had been cultured for several generations in the presence of Em were washed and transferred to medium without antibiotic. In two separate experiments, the cells were carried through 20 to 25 generations or through 30 to 35 generations in the absence of Em, then diluted and plated on medium with and without added Em. Spontaneous loss of Em resistance was calculated by dividing the number of c.f.u. present on plates containing Em by the number of c.f.u. on plates without the antibiotic. The results clearly demonstrated that the Em resistance factor was not stably maintained by $\beta$ plasmid transformants of strain DL8 in the absence of selective pressure. In contrast, strain DS5 produced no Em-sensitive colonies after nearly 25 generations in the absence of Em. The rate of spontaneous loss of Em resistance by the DL 8 transformants was calculated to be 3 to $4 \%$ per generation. None of the Em-sensitive isolates reverted to Em resistance. Loss of the Em-resistance phenotype was also accompanied by loss of resistance to $\mathrm{Lm}$. These spontaneously cured transformants had also lost the plasmid DNA, as determined by dye buoyant density gradient analyses of extracted DNA.

\section{Evidence for a restriction-modification system in strain DL8}

The frequency of transformation by heterologous chromosomal DNA in competent cultures of a group F streptococcus strain is considerably lower than the frequency of transformation of the same strain by homologous DNA (Perry \& Slade, 1962, 1964). This difference may be determined by the degree of homology between the genomes of the donor and recipient strains or by the possible presence of a host-specific restriction-modification system in the recipient. Transformation by plasmid DNA is not dependent upon the integration of the donor DNA into the recipient chromosome and would not be expected to be affected by the degree of homology between donor and recipient DNA. However, the transformation frequency should be decreased considerably, relative to a homologous plasmid, by a recipient restriction-modification system.

Portions of a culture of strain DL8 were mixed with $\mathrm{CCC} \beta$ plasmid DNA isolated either from strain DS5 or from a DL8 transformant (strain DL8-12). Throughout the competent phase the transformation frequency was always higher when $\beta$ plasmid from strain DL8-12 was the donor than when $\beta$ plasmid from strain DS5 served as donor DNA (Table 1). At maximum competence the difference in transformation frequency between the two plasmid 
preparations was nearly 100 -fold, suggesting that strain DL8 possesses a restriction-modification system which reduces the frequency of transformation by plasmid DNA isolated from a heterologous donor strain.

\section{DISCUSSION}

Transformation of streptococci by plasmid DNA has now been demonstrated in members of two Lancefield groups, $\mathrm{H}$ and F (LeBlanc \& Hassell, 1976; this communication). When the $\beta$ plasmid DNA in transformed group H $S$. sanguis was isolated and characterized it did not have the same physical characteristics as $\beta$ plasmid DNA isolated from the original group D host, $S$. faecalis strain Ds5. The major differences were the smaller size of the plasmid from $S$. sanguis and the apparent instability of the covalently closed circular form of the molecule. The $\beta$ plasmid from transformed group $F$ streptococci behaved identically to the original Ds5 plasmid in size, configuration and stability. However, although the $\beta$ plasmid from DS5 and transformed DL 8 strains appeared to share the same physical properties, strain DL8 was unable to retain the plasmid in the absence of selective pressure. This observation may reflect a deficiency in the replication of the plasmid DNA, possibly a host-required enzyme which is limiting and/or an accumulation of a replicative intermediate. The presumed dimeric form of $\beta$ sedimenting in neutral sucrose gradients (Fig. $2 a$ ) at $56 \mathrm{~S}$ may be such a replicative intermediate. This form typically represented 10 to $20 \%$ of the total plasmid DNA present in cell extracts, and in at least one experiment accounted for nearly $50 \%$ of the total plasmid DNA. The speculative limiting step, in this case, may lie in the separation of a completed replicate into two progeny molecules. Both the nature of this $56 \mathrm{~S}$ species and its role, if any, in the replication of $\beta$ plasmid DNA are currently being examined.

Restriction-modification systems are ubiquitous in both Gram-positive and Gramnegative bacteria (Arber, 1974; Boyer, 1971; Meselson, Yuan \& Heywood, 1972). Among the streptococci, such systems have been reported in three strains of Streptococcus cremoris (Collins, 1956), and a restriction endonuclease has been purified and characterized from a strain of $S$. faecalis (R. Wu, personal communication). The $\beta$ plasmid from transformed DL8 strains proved useful in obtaining preliminary data suggesting the presence of a type of restriction-modification system in these cells. Efforts are now being directed toward the isolation of a restriction-deficient mutant of strain DL.8. Such a strain would provide a potential recipient for plasmids isolated from virtually any species of streptococci at considerably higher than normal transformation frequencies.

\section{REFERENCES}

ARBER, W. (1974). DNA modification and restriction. Progress in Nucleic Acid Research (and Molecular Biology) 14, 1-37.

BOYER, H. W. (1971). DNA restriction and modification mechanisms in bacteria. Annual Review of Biochemistry 40, 153-176.

Clewell, D. B., Yagi, Y., DunNy, G. M. \& SCHULTZ, S. K. (1974). Characterization of three plasmid deoxyribonucleic acid molecules in a strain of Streptococcus faecalis: identification of a plasmid determining erythromycin resistance. Journal of Bacteriology 117, 283-289.

Collins, E. B. (1956). Host-controlled variations in bacteriophages active against lactic streptococci. Virology 2, 261-271.
LeBlanc, D. J. \& Hassell, F. P. (1976). Transformation of Streptococcus sanguis Challis by plasmid deoxyribonucleic acid from Streptococcus faecalis. Journal of Bacteriology 128, 347-355.

Meselson, M., Yuan, R. \& Heywood, J. (1972). Restriction and modification of DNA. Annual Review of Biochemistry 41, 447-466.

Perry, D. \& Slade, H. D. (1962). Transformation of streptococci to streptomycin resistance. Journal of Bacteriology 83, 443-449.

Perry, D. \& Slade, H. D. (1964). Intraspecific and interspecific transformation in streptococci. Journal of Bacteriology 88, 595-601. 